\title{
Trends in self-reported traumatic brain injury among Canadians, 2005-2014: a repeated cross-sectional analysis
}

\author{
Deepa P. Rao PhD, Steven McFaull MSc, Wendy Thompson MSc, Gayatri C. Jayaraman PhD
}

\section{Abstract}

Background: Concussion and other traumatic brain injuries (TBIs) are a form of unintentional injury that has been associated with both short- and long-term health effects, including possible disability. We investigated time trends in the incidence of all types of injury and TBls among Canadians, and assessed characteristics of TBls.

Methods: We used data from annual cycles of the Canadian Community Health Survey, 2005 to 2014, to examine all types of injury and TBI among Canadians aged 12 years or more. We estimated TBI incidence among respondents who reported any type of injury in the previous year. We used descriptive methods to describe key characteristics (sex, age, season, activity and venue) and 5- and 10-year trends, and generalized linear models to estimate annual percent change in the incidence of all types of injury and TBI.

Results: The incidence of all types of injury and of TBls increased between 2005 and 2014, with an annual percent change of 1.4 (95\% confidence interval [Cl] 0.9-1.9) and 9.6 (95\% Cl 8.2-11.0), respectively. Sport venues (39.9\% [95\% Cl 32.7-47.1)] and sportsrelated activities $(49.7 \%$ [95\% $\mathrm{Cl} 42.4-57.0])$ were commonly associated with TBIs, and falls were the most frequent mechanism of injury (53.9\% [95\% Cl 46.7-61.0]) leading to a TBI.

Interpretation: Our findings highlight the increasing trends in all types of injury and TBls in Canada, and underscore the need for ongoing population level surveillance and targeted prevention efforts to mitigate risk.

U nintentional injuries are the fifth-leading cause of death in Canada and the leading cause of death among those 1-44 years of age. ${ }^{1}$ They accounted for $4.4 \%$ of deaths in this country in $2011^{1}$ and cost Canadians about $\$ 26.8$ billion in $2010 .{ }^{2}$ Unintentional injuries include traumatic brain injury (TBI), ${ }^{3}$ which is induced by biomechanical forces caused by a direct blow to the head, face, neck or elsewhere on the body with an impulsive force transmitted to the head, resulting in rapid onset of short-lived impairment of neurologic function. ${ }^{4}$ Since TBIs can span a wide range of severity, the term concussion is often used to refer to a mild TBI, although this varies according to professional society or organization. Immediate signs and symptoms of a TBI include fogginess, memory disturbances and vomiting, but symptoms may not show up for hours or days after the injury. A range of acute and/or chronic neurobehavioural symptoms (somatic, cognitive and emotional/behavioural) may be seen in the weeks and months following injury. ${ }^{5}$

There have been few studies looking into population-level estimates of TBI among Canadians. In the current paper we report on key characteristics and 5-and 10-year trends in the annual cumulative incidence of TBI in the general Canadian population. For our purposes, we report on the full spectrum of TBIs and do not distinguish them based on severity.

\section{Methods}

\section{Source of data}

Data from the Canadian Community Health Survey (CCHS) were used for the present study. The CCHS is a cross-sectional population health survey of Canadians aged 12 years or more, not including those living in nursing homes or long-term care

Competing interests: None declared.

This article has been peer reviewed.

Correspondence to: Deepa Rao, deepa.rao@canada.ca

CMAJ Open 2017. DOI:10.9778/cmajo.20160115 
facilities or on reserves, full-time members of the Canadian Armed Forces and civilian residents of military bases. Details about the survey methodology are described elsewhere. ${ }^{6}$ The CCHS collects self-reported data regarding a range of measures related to health status, use of health care services and health determinants. We used annual cycles of the CCHS, 2005 to 2014, to examine the cumulative incidence of TBI among Canadians. Only data from cycles of the CCHS that included the same injury module as common content (i.e., asked to all respondents) were included for this analysis. Therefore, years 2005, 2009, 2010, 2013 and 2014 were used.

\section{Definitions}

Respondents were asked to identify whether they had experienced an injury in the previous 12 months. Those who had had an injury were then asked to identify the type of their most serious injury from a list of possible options, including "concussion or other brain injury." By definition, all cases of TBI reported in this study refer to nonfatal cases. Responses were then used to examine characteristics associated with the injury, including the environment in which the injury occurred (place of injury, month, activity the person was involved in) and the mechanism of injury.

Responses for mechanism of injury included fall, transportation crash, contact with a person (recorded as "bumped, pushed, bitten"), contact with an object (recorded as "struck or crushed by object[s]"), contact with sharp object, smoke, contact with hot object, extreme weather, overexertion, physical assault and other. The place of injury was grouped as follows: home (home or residential institution), school (school or other institution), athletics area (sports area in school or elsewhere), street (street, highway, sidewalk) or other (commercial, industrial or construction area; farm; countryside). Activities were defined as sports, leisure (hobbies, going up or down stairs, personal care, walking), work (working at a job or business), household chores or other unpaid work, driving or being a passenger in a motor vehicle, or other. Given the impact of seasonality on injuries, ${ }^{7}$ we created a derived variable for the 4 seasons based on responses regarding the month of injury: winter (December-February), spring (March-May), summer (June-August and fall (September-November). Variable details are included in Appendix 1 (available at www.cmajopen. ca/content/5/2/E301/suppl/DC1).

\section{Statistical analyses}

We performed analyses using SAS Enterprise Guide version 5.1 (SAS Institute). All estimates of TBI reflect annual cumulative incidence among Canadians who reported an injury in the previous year. Mean and incidence estimates were weighted to reflect the Canadian household population, and 95\% confidence intervals (CIs) were calculated with the use of bootstrap resampling methods. We used generalized linear models to estimate annual percent change. Estimates are presented for all ages ( $\geq 12 \mathrm{yr}$ ) as well as disaggregated for youth (12-17 yr) and adults ( $\geq 18 \mathrm{yr})$. Some results are presented with an $\mathrm{E}^{*}$ to indicate that they have high sampling variability (coefficient of variation $16.6 \%-33.3 \%$ ) and should be inter- preted with caution where indicated. We used all cycles of the CCHS with national level estimates for TBI to describe overall time trends. We examined 5- and 10-year trends using data from 2005, 2009 and 2014, and examined TBI characteristics using a pooled 2013 and 2014 file.

\section{Results}

\section{Trends in injuries of all types}

Rates of all types of injury increased between 2005 and 2014, with the proportion of Canadians reporting an injury rising by $1.4 \%$ (95\% CI 0.9-1.9) annually. Increases were observed among both youth and adults (annual percent change 0.8 [95\% CI 0.4-1.2] and 1.7 [95\% CI 1.3-2.1], respectively). There were significant differences in annual percent change based on age group, with a significant decrease for those aged 12-17 (annual percent change -2.6 [95\% CI -3.4 to -1.8]) and a significant increase for those 60 years or more (annual percent change 4.4 [95\% CI 3.1-5.7]). Although females reported significantly fewer injuries than males for all age groups (except among youth, where differences did not exist in recent years) (Table 1), the annual percent change for females was significantly greater than that for males $(2.5[95 \%$ CI 1.9-3.0] v. 0.4 [95\% CI 0.0-0.9]) (Figure 1). The mean number of injuries per person in the previous year also increased significantly, from an average of 1.5 in 2005 to 1.6 in 2014 (Table 1).

\section{Trends in TBI}

The incidence of TBI more than doubled over the study period: the proportion of Canadians who reported having a TBI in 2014 was $3.2 \%$, compared to $1.4 \%$ in 2005 (Figure 2, Table 1). The annual percent change was 9.6 (95\% CI $8.2-$ 11.0) for all ages, 10.3 (95\% CI 2.5-18.1 $\mathrm{E}^{*}$ for youth and 9.7 (95\% CI 9.4-10.0) for adults (Figure 1). Combining our finding of incidence rate of all types of injuries (15.7\%) with the incidence rate of TBIs among those injuries (3.2\%) in 2014, we estimate an overall incidence rate of TBI of $0.5 \%$. Based on a population count from 2014 of people aged 12 years or more of roughly 31 million, ${ }^{8}$ we estimate that there were about 155000 TBIs during that year. Among specific age ranges, significant increases were observed only for those aged 18-34 years (annual percent change 2.1 [95\% CI 1.7-2.5]). No significant between-sex differences in TBI incidence were observed (Table 1). However, the annual percent change was higher for females than males, although not significantly so (Figure 1). The mean number of injuries of all types among those with a TBI and those without a TBI did not differ significantly (Table 1).

\section{Characteristics of TBIs}

Most TBIs were reported to have occurred in a sports or athletics area in a school or other venue $399.9 \%$ [95\% CI $32.7-$ 47.1] for all ages, 66.4\% [95\% CI 56.4-76.4] for youth and $30.4 \%$ [95\% CI 21.8-39.0] for adults in 2013-2014). This tendency was more evident among youth than adults, with adults experiencing TBIs in other venues, such as the home 
(24.9\% [95\% CI 18.1-31.7] in 2013-2014) (data not shown). The most prevalent activity associated with TBI, sports (49.7\% [95\% CI 42.4-57.0] among all ages), mirrored the most prevalent venue of injury. Among youth, most TBIs occurred during a sports-based activity $(86.3 \%$ [95\% CI 79.992.7]), whereas among adults, the type of activity was more diverse (Table 2). The most common mechanism of the TBI was a fall $(53.9 \%$ [95\% CI 46.7-61.0] for all ages, $57.7 \%$ [95\% CI 47.4-67.9] for youth and 52.5\% [95\% CI 43.4-61.6] for adults). Contact with a person or object were the second and third most frequently reported mechanisms, respectively (contact with person: $18.0 \%$ [95\% CI 10.9-25.0 $\mathrm{E}^{*}$ ] for all ages, $25.9 \%$ [95\% CI 16.5-35.3 $\mathrm{E}^{*}$ ] for youth and $15.1 \%$ [95\% CI 6.0-24.3 E*] for adults in 2013-2014; contact with object: $11.8 \%$ [95\% CI 7.1-16.4 $\left.\mathrm{E}^{*}\right]$ for all ages, $9.5 \%[95 \%$ CI $3.8-15.1 \mathrm{E}^{*}$ ] for youth and $12.6 \%$ [95\% CI $6.7-18.5 \mathrm{E}^{*}$ ] for adults in 2013-2014) (data not shown).

No significant between-season differences in TBI incidence were noted for all ages (data not shown). However, for youth, the incidence was significantly higher in the fall (Figure 3).

\begin{tabular}{|c|c|c|c|c|c|}
\hline \multirow[b]{2}{*}{ Variable } & & \multicolumn{3}{|c|}{ Year; \% $(95 \% \mathrm{Cl})^{*}$} & \multirow{2}{*}{$\begin{array}{c}\text { Annual \% change } \\
(95 \% \mathrm{Cl})\end{array}$} \\
\hline & & 2005 & 2009 & 2014 & \\
\hline \multicolumn{6}{|c|}{ All types of injury } \\
\hline \multicolumn{2}{|l|}{ Youth† } & $\begin{array}{c}25.4 \\
(24.3 \text { to } 26.4)\end{array}$ & $\begin{array}{c}26.7 \\
(25.0 \text { to } 28.4)\end{array}$ & $\begin{array}{c}27.4 \\
\text { (25.4 to } 29.3)\end{array}$ & $\begin{array}{c}0.8 \\
(0.4 \text { to } 1.2)\end{array}$ \\
\hline \multicolumn{2}{|l|}{ Adults $\ddagger$} & $\begin{array}{c}12.6 \\
(12.3 \text { to } 12.9)\end{array}$ & $\begin{array}{c}13.7 \\
(13.2 \text { to } 14.2)\end{array}$ & $\begin{array}{c}14.7 \\
(14.1 \text { to } 15.2)\end{array}$ & $\begin{array}{c}1.7 \\
(1.3 \text { to } 2.1)\end{array}$ \\
\hline \multicolumn{2}{|l|}{ Youth } & $\begin{array}{c}1.9 \\
(1.8 \text { to } 12.0)\end{array}$ & $\begin{array}{c}2.0 \\
(1.8 \text { to } 2.2)\end{array}$ & $\begin{array}{c}2.1 \\
\text { (1.9 to } 2.3)\end{array}$ & $\begin{array}{c}1.3 \\
(1.1 \text { to } 1.6)\end{array}$ \\
\hline \multicolumn{2}{|l|}{ Adults } & $\begin{array}{c}1.4 \\
(1.4 \text { to } 1.5)\end{array}$ & $\begin{array}{c}1.5 \\
(1.5 \text { to } 1.6)\end{array}$ & $\begin{array}{c}1.6 \\
(1.5 \text { to } 1.6)\end{array}$ & $\begin{array}{c}1.1 \\
(0.2 \text { to } 2.0)\end{array}$ \\
\hline \multicolumn{6}{|c|}{ Incidence by age group, yr } \\
\hline \multicolumn{2}{|l|}{$12-17$} & $\begin{array}{c}17.2 \\
(16.5 \text { to } 17.9)\end{array}$ & $\begin{array}{c}16.0 \\
(15.0 \text { to } 17.0)\end{array}$ & $\begin{array}{c}13.6 \\
(12.7 \text { to } 14.6)\end{array}$ & $\begin{array}{c}-2.6 \\
(-3.4 \text { to }-1.8)\end{array}$ \\
\hline \multicolumn{2}{|l|}{$18-34$} & $\begin{array}{c}32.0 \\
\text { (31.1 to 33.0) }\end{array}$ & $\begin{array}{c}32.4 \\
(30.8 \text { to } 33.9)\end{array}$ & $\begin{array}{c}31.1 \\
(29.5 \text { to } 32.7)\end{array}$ & $\begin{array}{c}-0.3 \\
(-1.0 \text { to } 0.3)\end{array}$ \\
\hline \multicolumn{2}{|l|}{$35-59$} & $\begin{array}{c}38.3 \\
(37.2 \text { to } 39.3)\end{array}$ & $\begin{array}{c}37.6 \\
(36.0 \text { to } 39.2)\end{array}$ & $\begin{array}{c}37.0 \\
(35.4 \text { to } 38.7)\end{array}$ & $\begin{array}{c}-0.4 \\
(-0.5 \text { to }-0.3)\end{array}$ \\
\hline \multirow[t]{2}{*}{ Youth } & Males & $\begin{array}{c}29.7 \\
\text { (28.1 to } 31.3)\end{array}$ & $\begin{array}{c}29.1 \\
(26.5 \text { to } 31.8)\end{array}$ & $\begin{array}{c}29.0 \\
(26.3 \text { to } 31.8)\end{array}$ & $\begin{array}{c}-0.3 \\
(-0.5 \text { to } 0.0)\end{array}$ \\
\hline & Females & $\begin{array}{c}20.7 \\
(19.2 \text { to } 22.1)\end{array}$ & $\begin{array}{c}24.1 \\
21.8 \text { to } 26.5\end{array}$ & $\begin{array}{c}25.6 \\
\text { (22.8 to } 28.3)\end{array}$ & $\begin{array}{c}2.2 \\
(0.8 \text { to } 3.6)\end{array}$ \\
\hline \multirow[t]{2}{*}{ Adults } & Males & $\begin{array}{c}14.9 \\
(14.4 \text { to } 15.4)\end{array}$ & $\begin{array}{c}15.7 \\
(14.9 \text { to } 16.5)\end{array}$ & $\begin{array}{c}16.0 \\
(15.2 \text { to } 16.9)\end{array}$ & $\begin{array}{c}0.8 \\
(0.3 \text { to } 1.3)\end{array}$ \\
\hline & Females & $\begin{array}{c}10.5 \\
(10.1 \text { to } 10.8)\end{array}$ & $\begin{array}{c}11.8 \\
\text { (11.2 to } 12.4)\end{array}$ & $\begin{array}{c}13.4 \\
(12.8 \text { to } 14.1)\end{array}$ & $\begin{array}{c}2.7 \\
(2.5 \text { to } 2.9)\end{array}$ \\
\hline
\end{tabular}




\section{OPEN}

Research

\begin{tabular}{|c|c|c|c|c|c|}
\hline \multirow[b]{2}{*}{ Variable } & & \multicolumn{3}{|c|}{ Year; \% $(95 \% \mathrm{Cl})^{*}$} & \multirow{2}{*}{$\begin{array}{c}\text { Annual \% change } \\
(95 \% \mathrm{Cl})\end{array}$} \\
\hline & & 2005 & 2009 & 2014 & \\
\hline \multicolumn{6}{|c|}{ Traumatic brain injury§ } \\
\hline \multicolumn{6}{|l|}{ Incidence } \\
\hline \multicolumn{2}{|l|}{ All ages } & $\begin{array}{c}1.4 \\
(1.2 \text { to } 1.7)\end{array}$ & $\begin{array}{c}1.9 \\
(1.4 \text { to } 2.4)\end{array}$ & $\begin{array}{c}3.2 \\
(2.6 \text { to } 3.9)\end{array}$ & $\begin{array}{c}9.6 \\
\text { (8.2 to } 11.0)\end{array}$ \\
\hline \multicolumn{2}{|l|}{ Youth } & $\begin{array}{c}2.7 \\
(2.0 \text { to } 3.4)\end{array}$ & $\begin{array}{c}2.7 \\
(1.7 \text { to } 3.8)\end{array}$ & $\begin{array}{c}5.7 \\
(4.1 \text { to } 7.3)\end{array}$ & $\begin{array}{c}10.3 \rrbracket \\
(2.5 \text { to } 18.1)\end{array}$ \\
\hline \multicolumn{2}{|l|}{ Adults } & $\begin{array}{c}1.2 \\
(0.9 \text { to } 1.4)\end{array}$ & $\begin{array}{c}1.8 \\
(1.2 \text { to } 2.4)\end{array}$ & $\begin{array}{c}2.9 \\
(2.2 \text { to } 3.5)\end{array}$ & $\begin{array}{c}9.7 \\
(9.4 \text { to } 10.0)\end{array}$ \\
\hline \multicolumn{6}{|c|}{ No. of injuries of any type by presence of TBI, mean $(95 \% \mathrm{Cl})$} \\
\hline \multirow[t]{2}{*}{ All ages } & TBI & $\begin{array}{c}1.5 \\
(1.4 \text { to } 1.3)\end{array}$ & $\begin{array}{c}1.6 \\
(1.6 \text { to } 1.7)\end{array}$ & $\begin{array}{c}1.6 \\
(1.6 \text { to } 1.7)\end{array}$ & $\begin{array}{c}0.7 \\
(-0.2 \text { to } 1.5)\end{array}$ \\
\hline & No TBI & $\begin{array}{c}2.0 \\
\text { (1.7 to } 2.3)\end{array}$ & $\begin{array}{c}1.7 \\
(1.3 \text { to } 2.1)\end{array}$ & $\begin{array}{c}1.7 \\
(1.3 \text { to } 2.1)\end{array}$ & $\begin{array}{c}-1.8 \\
(-4.1 \text { to } 0.5)\end{array}$ \\
\hline \multirow[t]{2}{*}{ Youth } & $\mathrm{TBI}$ & $\begin{array}{c}1.8 \\
\text { (1.7 to } 2.0)\end{array}$ & $\begin{array}{c}2.0 \\
\text { (1.8 to } 2.2)\end{array}$ & $\begin{array}{c}2.1 \\
\text { (1.9 to } 2.3)\end{array}$ & $\begin{array}{c}1.6 \\
(0.7 \text { to } 2.5)\end{array}$ \\
\hline & No TBI & $\begin{array}{c}2.2 \\
\text { (1.6 to } 2.8)\end{array}$ & $\begin{array}{c}2.5 \\
(1.0 \text { to } 3.9)\end{array}$ & $\begin{array}{c}1.9 \\
(1.6 \text { to } 2.2)\end{array}$ & $\begin{array}{c}-1.6 \\
(-6.5 \text { to } 3.3)\end{array}$ \\
\hline \multirow[t]{2}{*}{ Adults } & $\mathrm{TBI}$ & $\begin{array}{c}1.4 \\
(1.4 \text { to } 1.5)\end{array}$ & $\begin{array}{c}1.5 \\
(1.5 \text { to } 1.6)\end{array}$ & $\begin{array}{c}1.6 \\
(1.5 \text { to } 1.6)\end{array}$ & $\begin{array}{c}1.5 \\
(1.2 \text { to } 1.7)\end{array}$ \\
\hline & No TBI & $\begin{array}{c}1.9 \\
\text { (1.5 to } 2.3 \text { ) }\end{array}$ & $\begin{array}{c}1.5 \\
(1.2 \text { to } 1.8)\end{array}$ & $\begin{array}{c}1.7 \\
\text { (1.2 to } 2.2)\end{array}$ & $\begin{array}{c}-1.2 \\
(-6.0 \text { to } 3.5)\end{array}$ \\
\hline \multicolumn{6}{|c|}{ Incidence by age group, yr } \\
\hline \multicolumn{2}{|l|}{$12-17$} & $\begin{array}{c}31.9 \\
\text { (25.1 to } 38.8)\end{array}$ & $\begin{array}{c}22.79 \\
(13.7 \text { to } 31.7)\end{array}$ & $\begin{array}{c}23.9 \\
(16.8 \text { to } 31.0)\end{array}$ & $\begin{array}{c}-3.5 \\
(-9.0 \text { to } 2.0)\end{array}$ \\
\hline \multicolumn{2}{|l|}{$18-34$} & $\begin{array}{c}35.1 \\
\text { (27.7 to } 42.5)\end{array}$ & $\begin{array}{c}37.5 \\
(25.6 \text { to } 49.3)\end{array}$ & $\begin{array}{c}42.3 \\
\text { (31.6 to } 53.0)\end{array}$ & $\begin{array}{c}2.1 \\
\text { (1.7 to } 2.5)\end{array}$ \\
\hline \multicolumn{2}{|l|}{$35-59$} & $\begin{array}{c}24.7 \\
(17.6 \text { to } 31.8)\end{array}$ & $\begin{array}{c}32.59 \\
\text { (19.7 to 45.2) }\end{array}$ & $\begin{array}{c}27.2 \\
(19.4 \text { to } 35.0)\end{array}$ & $\begin{array}{c}0.7 \\
(-5.0 \text { to } 6.5)\end{array}$ \\
\hline \multicolumn{2}{|l|}{$\geq 60$} & $\begin{array}{c}8.29 \\
(4.7 \text { to } 11.8)\end{array}$ & $\begin{array}{c}7.39 \\
\text { (3.1 to } 11.5 \text { ) }\end{array}$ & $\begin{array}{c}6.6 \text { - } \\
\text { (3.5 to } 9.7)\end{array}$ & $\begin{array}{c}-2.4 \\
(-2.9 \text { to }-1.9)\end{array}$ \\
\hline \multicolumn{6}{|c|}{ Incidence by sex } \\
\hline \multirow[t]{2}{*}{ All ages } & Males & $\begin{array}{c}1.4 \\
(1.0 \text { to } 1.7)\end{array}$ & $\begin{array}{c}2.1 \\
\text { (1.4 to } 2.8)\end{array}$ & $\begin{array}{c}2.8 \\
\text { (2.1 to } 3.5)\end{array}$ & $\begin{array}{c}7.2 \\
(4.9 \text { to } 9.4)\end{array}$ \\
\hline & Females & $\begin{array}{c}1.5 \\
(1.2 \text { to } 1.9)\end{array}$ & $\begin{array}{c}1.7 \\
(1.0 \text { to } 2.3)\end{array}$ & $\begin{array}{c}3.7 \\
\text { (2.7 to } 4.7)\end{array}$ & $\begin{array}{c}12.09 \\
\text { (5.6 to 18.4) }\end{array}$ \\
\hline \multirow[t]{2}{*}{ Youth } & Males & $\begin{array}{c}2.7 \\
\text { (1.8 to } 3.5)\end{array}$ & $\begin{array}{c}3.4 \\
(2.0 \text { to } 4.8)\end{array}$ & $\begin{array}{c}5.7 \\
\text { (3.4 to } 7.9)\end{array}$ & $\begin{array}{c}8.9 \\
\text { (6.5 to 11.3) }\end{array}$ \\
\hline & Females & $\begin{array}{c}2.6 \\
\text { (1.5 to } 3.8 \text { ) }\end{array}$ & $\begin{array}{c}1.9 \\
(0.4 \text { to } 3.5)\end{array}$ & $\begin{array}{c}5.8 \\
\text { (3.3 to } 8.2)\end{array}$ & $\begin{array}{c}13.3 \\
(-2.6 \text { to } 23.3)\end{array}$ \\
\hline \multirow[t]{2}{*}{ Adults } & Males & $\begin{array}{c}1.1 \\
(0.7 \text { to } 1.4)\end{array}$ & $\begin{array}{c}1.9 \\
\text { (1.1 to } 2.7)\end{array}$ & $\begin{array}{c}2.4 \\
(1.6 \text { to } 3.1)\end{array}$ & $\begin{array}{c}7.5 \\
\text { (2.9 to } 12.1)\end{array}$ \\
\hline & Females & $\begin{array}{c}1.3 \\
(1.0 \text { to } 1.7)\end{array}$ & $\begin{array}{c}1.6 \\
(0.9 \text { to } 2.4)\end{array}$ & $\begin{array}{c}3.4 \\
(2.3 \text { to } 4.6)\end{array}$ & $\begin{array}{c}12.3 \\
\text { (7.2 to } 17.4)\end{array}$ \\
\hline \multicolumn{6}{|c|}{$\begin{array}{l}\text { Note: } \mathrm{Cl}=\text { confidence interval, } \mathrm{TBI} \text { = traumatic brain injury. } \\
{ }^{*} \mathrm{Except} \text { where noted otherwise. } \\
\text { †Age } 12-17 \text { years. } \\
\text { †Age } \geq 18 \text { years. } \\
\text { §Among people who reported any type of injury in the previous year. } \\
\text { qInterpret with caution owing to high sampling variability (coefficient }\end{array}$} \\
\hline
\end{tabular}




\section{Interpretation}

Our findings show a significant increase in the incidence of nonfatal injuries of all types and in TBIs between 2005 and 2014 in Canada. In a population of over 30 million, this sug- gests that $0.5 \%$ of Canadians aged 12 years or more, or roughly 155000 people, experienced a TBI in 2014. People aged 18-34 years accounted for more than a third of those affected. Although the incidence of TBI decreased among respondents aged 60 years or more over the study period, the

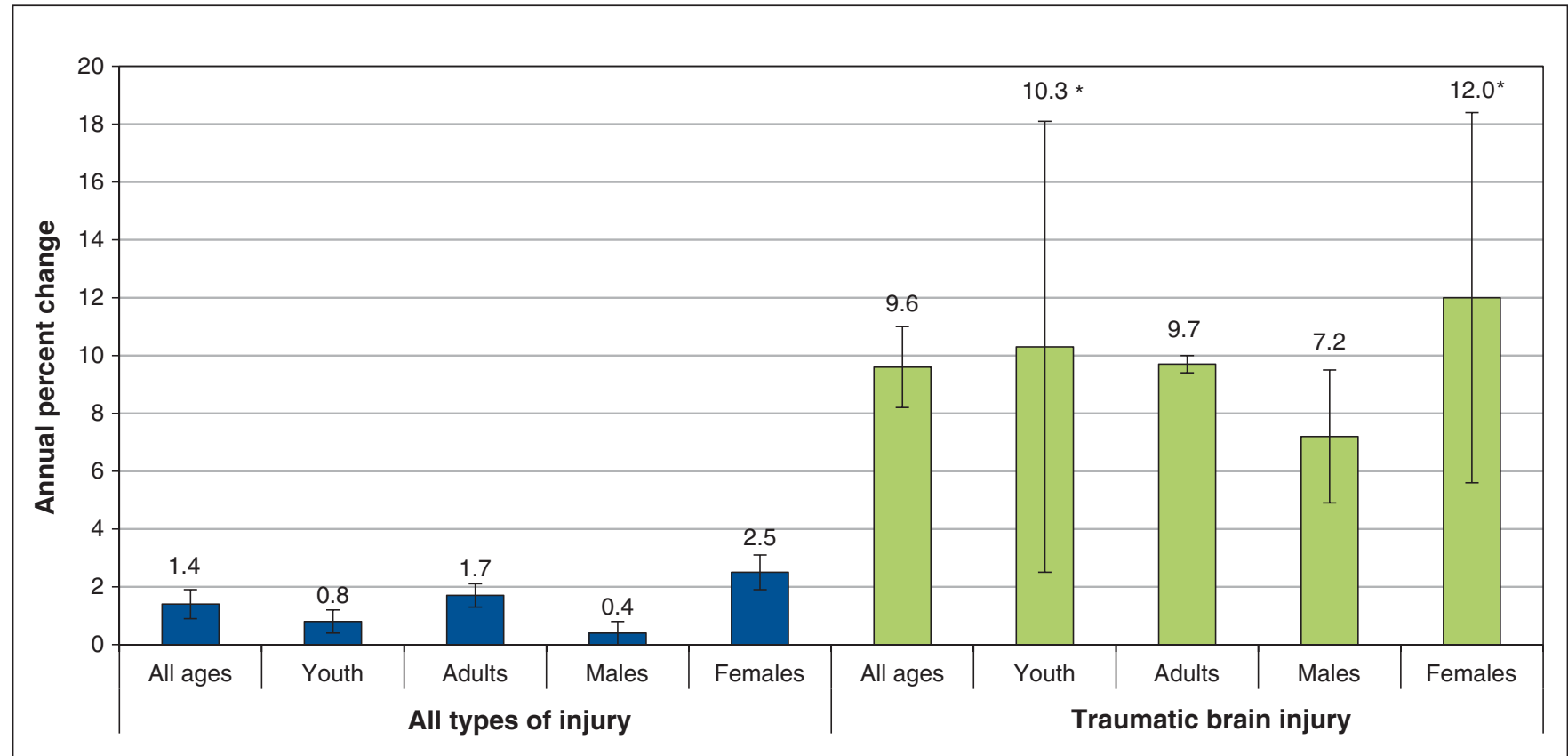

Figure 1: Annual percent change in the incidence of all types of injury and traumatic brain injury (among all respondents who reported any type of injury in the previous year) among all Canadians and by age group and sex. Youth $=12-17$ years, adults $=\geq 18$ years. ${ }^{*}$ Interpret with caution owing to high sampling variability (coefficient of variation $16.6 \%-33.3 \%$ ).

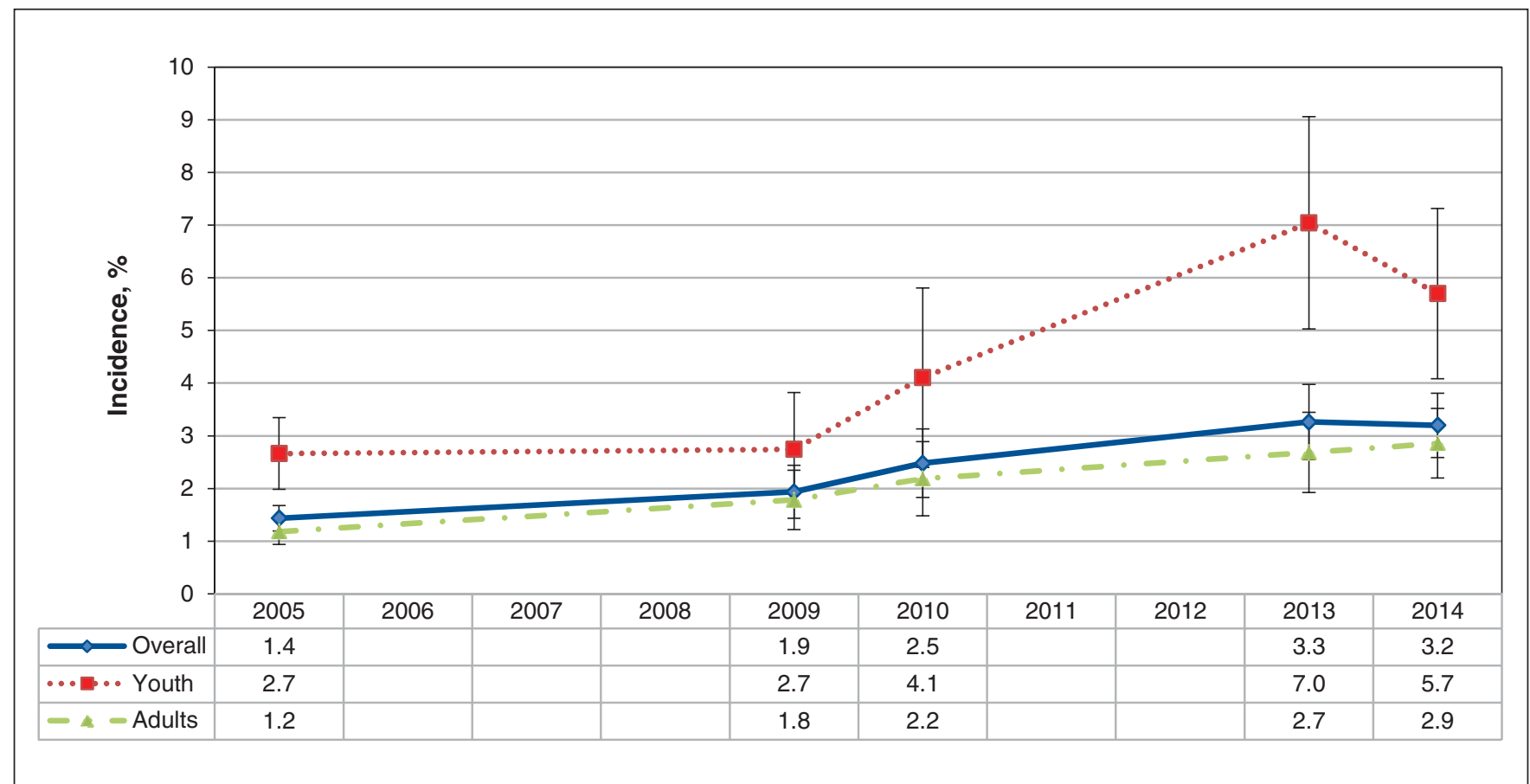

Figure 2: Trends in the incidence of traumatic brain injury among Canadians, overall and by age group, 2005-2014. Estimates are reported among all respondents who reported any type of injury in the previous year. 
incidence of injuries of any type increased significantly in that age group. Differences in the incidence of any type of injury over time were significant between the sexes, but differences in TBI incidence were not. Nevertheless, the increasing trend over time in the incidence of TBI among females relative to males is of note. There were no differences in number of injuries of any type between respondents with a TBI and those without a TBI. However, while the mean number of injuries of any type increased significantly over time among those who

\begin{tabular}{|c|c|c|c|}
\hline \multirow[b]{2}{*}{ Activity } & \multicolumn{3}{|c|}{$\%(95 \% \mathrm{Cl})$} \\
\hline & All ages & Youth & Adults \\
\hline Sports & $\begin{array}{c}49.7 \\
(42.4-57.0)\end{array}$ & $\begin{array}{c}86.3 \\
(79.9-92.7)\end{array}$ & $\begin{array}{c}36.6 \\
(27.9-45.4)\end{array}$ \\
\hline Leisure & $\begin{array}{c}20.1 \\
(14.9-25.4)\end{array}$ & $\begin{array}{c}8.3 \\
(2.7-13.8)^{*}\end{array}$ & $\begin{array}{c}24.4 \\
(17.6-31.1)\end{array}$ \\
\hline Work & $\begin{array}{c}9.0 \\
(5.3-12.7)^{\star}\end{array}$ & $-\dagger$ & $\begin{array}{c}12.2 \\
(7.1-17.4)^{*}\end{array}$ \\
\hline $\begin{array}{l}\text { Household } \\
\text { chores }\end{array}$ & $\begin{array}{c}6.1 \\
(3.2-9.0)^{*}\end{array}$ & $-\dagger$ & $\begin{array}{c}7.8 \\
(3.8-11.8)^{*}\end{array}$ \\
\hline $\begin{array}{l}\text { Driver/ } \\
\text { passenger in } \\
\text { motor vehicle }\end{array}$ & $\begin{array}{c}7.9 \\
(3.3-12.5)^{*}\end{array}$ & $-\dagger$ & $\begin{array}{c}10.0 \\
(3.9-16.1)^{*}\end{array}$ \\
\hline \multicolumn{4}{|c|}{$\begin{array}{l}\text { Note: } \mathrm{Cl}=\text { confidence interval. } \\
\text { *Interpret with caution owing to high sampling variability (coefficient of variation } \\
\text { between } 16.6 \% \text { and } 33.3 \% \text { ). } \\
\text { tUnable to report (coefficient of variation }>33.3 \% \text { ). }\end{array}$} \\
\hline
\end{tabular}

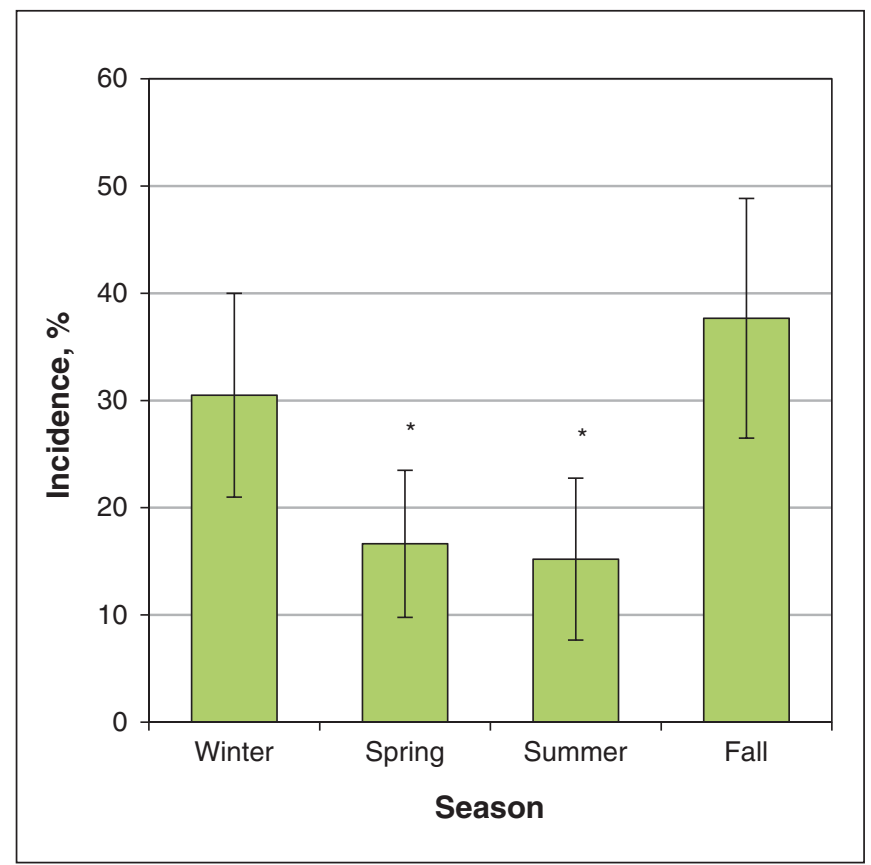

Figure 3: Incidence of traumatic brain injury among youth by season. *Interpret with caution owing to high sampling variability (coefficient of variation $16.6 \%-33.3 \%)$. reported a TBI, they decreased significantly among those who did not report a TBI. Although it was not possible to examine the type of subsequent non-TBI injury among those who reported multiple injuries, the trend toward reporting repeat injuries among those who reported a TBI is noteworthy. TBIs were most commonly associated with sports-related activities, particularly among youth, as well as occupation among adults. Sports and athletics venues were identified as the most common venues for TBI. The observation that TBIs occurred most commonly in fall and winter suggests an association with season-specific activities. Falls were the mechanism of injury most commonly associated with TBIs across all age groups, with contact with another person and contact with an object identified as the second and third most common mechanisms.

The observed increased incidence of all types of injuries and TBIs is consistent with observations in the United States. ${ }^{9,10}$ Our finding that the incidence of TBI increased significantly over the study period among people aged 18-34 years, as did the incidence of all types of injury among those aged 60 years or more, should inform public health efforts geared toward injury prevention. The former may reflect greater risk-taking behaviour of adolescents in sport. ${ }^{11}$ However, it is contrary to the understanding that a young brain concusses more easily than an adult one, ${ }^{12,13}$ since one would expect a higher incidence among those aged 12-17 years. The finding that the incidence of all types of injury increased among those aged 60 or more is also important because, in addition to the fact that injuries in older people are a catalyst for transition into long-term care, nonfatal injuries can commence a cascade of effects that affect health. ${ }^{14}$ Finally, the study by Guskiewicz and colleagues ${ }^{15}$ suggests that a previous history of TBI increases the probability of a second TBI relative to those who have not experienced a TBI. Therefore, it is possible that some of the repeat non-TBI injuries in our study may actually have been another TBI (and thereby potentially a second impact syndrome, if close in time) or another nonfatal non-TBI injury among those experiencing the effects of postconcussion syndrome. ${ }^{15}$

It has been suggested that females may be more susceptible to TBIs than males. ${ }^{12,16,17}$ Our finding of higher annual percent changes in all types of injury and TBIs among females, together with recent estimates from the Canadian Hospitals Injury Reporting and Prevention Program ${ }^{18}$ showing an increasing trend in head injuries, is concerning. Given the known challenges in keeping young girls active, ${ }^{19}$ these findings suggest that females are a population that may require special injury prevention efforts.

Activities related to sports, ${ }^{5,20}$ including winter sports, ${ }^{21}$ and motor vehicles crashes have been previously found to be associated with TBI. ${ }^{22}$ In a study of high school athletes, contact with another person was the risk factor responsible for most concussions; ${ }^{10,16}$ in our study, this mechanism was the second most common mechanism of injury among youth. Both fullcontact and partial-contact sports pose a risk. ${ }^{16-18}$ Recent emergency department surveillance records show a similar association between sport and head injuries among children and youth. ${ }^{18}$ 


\section{Limitations}

Our findings represent population-level Canadian estimates for nonfatal injuries of all types and TBIs based on selfreported data. The lack of national data from 2006-2008, 2011 and 2012 is a limitation, since they would have provided further reliability to our assessment of trends. Because surveys cannot capture fatal cases, and because the data source captured only TBIs that were identified as the most serious injury in the previous year, our estimates are likely an underestimate. However, since most TBIs (about 97\%, based on American data $^{10}$ ) are not fatal, these exclusions should not reduce the external validity of our findings. Internal validity may have been affected by respondent bias and the diminished validity of retrospective self-reported recall of injury. ${ }^{23}$ Since TBIs span a wide range of severity, our use of a single label serves as a limitation. In line with this consideration, it is possible that respondents with mild cases may not have identified their TBI within the year following their injury, as required for data capture in the survey, thereby resulting in underestimation of cases. Finally, although the estimates presented in the current analysis may reflect true increases, it is possible that improved awareness of TBI through national public health campaigns s.24 $^{3,2}$ may have improved identification and treatment practices and thereby better data collection sensitivity in national surveys.

\section{Conclusion}

We found increasing national trends in the incidence of all types of injury and of TBI among Canadians. These findings underscore the value of ongoing national surveillance. Our observation that sports activities and venues were the activity/ location most commonly associated with TBI should inform targeted prevention efforts. Furthermore, the fact that falls and contact with other people were the most common mechanism of TBI should assist with actions to limit such injury, especially given the suggested risk of full- and partial-contact sports. Future studies should aim to combine self-reported data with hospital records so as to better describe TBI injuries and their sequelae, distinguish TBI by their level of severity, since the implications can be quite distinct, and include people less than 12 years old, since young children are also at risk. Our findings should help inform health promotion and prevention efforts to mitigate future TBI events.

\section{References}

1. The 10 leading causes of death, 2011. Ottawa: Statistics Canada; 2011. Available: www.statcan.gc.ca/pub/82-625-x/2014001/article/11896-eng.htm (accessed 2016 Aug. 20).

2. The cost of injury in Canada. Toronto: Parachute; 2015.

3. National Center for Injury Prevention and Control. Report to Congress on mild traumatic brain injury in the United States: steps to prevent a serious public bealth problem. Atlanta: Centers for Disease Control and Prevention; 2003.

4. McCrory P, Meeuwisse W, Aubry M, et al. Consensus statement on concussion in sport - the 4th International Conference on Concussion in Sport held in Zurich, November 2012. Clin 7 Sport Med 2013;23:89-117.
5. Kirkwood MW, Yeates KO, Wilson PE. Pediatric sport-related concussion: a review of the clinical management of an oft-neglected population. Pediatrics 2006;117:1359-71.

6. Béland Y. Canadian community health survey - methodological overview. Health Rep 2002;13:9-14.

7. Jespersen E, Holst R, Franz C, et al. Seasonal variation in musculoskeletal extremity injuries in school children aged 6-12 followed prospectively over 2.5 years: a cohort study. BM7 Open 2014;4:e004165.

8. Table 051-0001. Estimates of population, by age group and sex for July 1, Canada, provinces and territories, annual (persons unless otherwise noted). CANSIM database. Ottawa: Statistics Canada; 2015. Available: www5.statcan.gc.ca/cansim/ a26?id=510001 (accessed 2016 June 4).

9. Coronado VG, McGuire LC, Sarmiento K, et al. Trends in traumatic brain injury in the U.S. and the public health response: 1995-2009. 7 Safety Res 2012;43:299-307.

10. Faul M, Xu L, Wald MM, et al. Traumatic brain injury in the United States: emergency department visits, hospitalizations and deaths 2002-2006. Atlanta: Centers for Disease Control and Prevention, National Center for Injury Prevention and Control; 2010.

11. Kontos AP. Perceived risk, risk taking, estimation of ability and injury among adolescent sport participants. 7 Pediatr Psychol 2004;29:447-55.

12. Tator CH. Concussions and their consequences: current diagnosis, management and prevention. CMA7 2013;185:975-9.

13. Baillargeon A, Lassonde M, Leclerc S, et al. Neuropsychological and neurophysiological assessment of sport concussion in children, adolescents and adults. Brain Inj 2012;26:211-20.

14. Seniors' falls in Canada: second report. Ottawa: Public Health Agency of Canada; 2014. Available: www.phac-aspc.gc.ca/seniors-aines/publications/public/injury -blessure/seniors_falls-chutes_aines/assets/pdf/seniors_falls-chutes_aines-eng. pdf (accessed 2016 Feb. 3)

15. Guskiewicz KM, McCrea M, Marshall SW, et al. Cumulative effects associated with recurrent concussion in collegiate football players: the NCAA Concussion Study. 7AMA 2003;290:2549-55.

16. Gessel LM, Fields SK, Collins CL, et al. Concussions among United States high school and collegiate athletes. F Atbl Train 2007;42:495-503.

17. Lincoln AE, Caswell SV, Almquist JL, et al. Trends in concussion incidence in high school sports: a prospective 11-year study. Am 7 Sports Med 2011;39: 958-63

18. McFaull S, Subaskaran J, Thompson W. Emergency department surveillance of injuries and head injuries associated with baseball, football, soccer and ice hockey, children and youth, ages 5 to 18 years, 2004 to 2014. Health Promot Chronic Dis Prev Can 2016;36:13-4.

19. Cavill N, Biddle S, Sallis JF. Health enhancing physical activity for young people: statement of the United Kingdom Expert Consensus Conference. Pediatr Exerc Sci 2001;13:12-25.

20. Head injuries in children and youth - the invisible epidemic. Ottawa: Public Health Agency of Canada; 2016. Available: http://infobase.phac-aspc.gc.ca/ datalab/head-injuries-blog-en.html (accessed 2016 Apr. 8).

21. Chaze B, McDonald P. Head injuries in winter sports: downhill skiing, snowboarding, sledding, snowmobiling, ice skating and ice hockey. Neurol Clin 2008;26:325-32; xii-xiii.

22. Concussion and motor vebicle collisions - exploring roadside options for first responders. Toronto: Ontario Injury Prevention Practitioners Network; 2015.

23. Gabbe BJ, Finch CF, Bennell KL, et al. How valid is a self reported 12 month sports injury history? Br 7 Sports Med 2003;37:545-7.

24. Funding to support active and safe participation in sports and recreation [fact sheet]. Ottawa: Public Health Agency of Canada. Available: www.phac-aspc. gc.ca/inj-bles/2012_0829-fs-fi-eng.php (accessed 2016 Apr. 5).

Affiliation: Surveillance and Epidemiology Division, Centre for Chronic Disease Prevention, Public Health Agency of Canada, Ottawa, Ont.

Contributors: Deepa Rao and Steven McFaull collaborated in designing the study. Deepa Rao was responsible for conducting the analyses and writing the initial draft of the manuscript. All of the authors participated in interpreting the data and revising the document for important intellectual content, approved the final version to be published and agreed to act as guarantors of the work.

Supplemental information: For reviewer comments and the original submission of this manuscript, please see www.cmajopen.ca/content/5/2/ E301/suppl/DC1 